\title{
The Effect of Transport Cost on Housing Affordability: Experiences from the Bandung Metropolitan Area, Indonesia
}

\begin{abstract}
Transport and housing costs are interrelated due to their substantial share of household budgets. In many cases, households are making trade-offs by either spending more on housing in the inner city with lower transport costs or choosing more affordable housing in suburban areas, with higher commuting cost. This paper aims to examine housing and transport affordability by exploring middle to low-income household's transport and housing expenses in the Bandung Metropolitan Area (BMA), Indonesia. Households in nine locations within BMA with various housing type and spatial characteristics were surveyed. Collected data from 405 households are used to measure variables including fuel, parking, maintenance cost, public transport fares spent by households, rent and 'owner equivalent rent'. This study proposes the data envelopment analysis (DEA) method to measure affordability. The analysis measures each housing location's performance in terms of housing and transport affordability. The results indicate that the overall affordability is affected by housing type, choice of transport modes and distance to work and school. This study contributes to the growing literature of both transport and housing affordability and has implications for policy in the urban, housing, and transport sectors in Indonesia.
\end{abstract}

Keywords: Affordability; Housing; Transport; Data Envelopment Analysis; Indonesia

\section{Introduction}

Housing affordability remains a major concern for housing studies and practice worldwide. Limited land supply for housing in urban areas and the rapid growth of urban population causes a tightening of affordable housing supply. This induces a rise in housing prices and decreasing affordability, particularly for low-income households. Cities tend towards urban spatial expansion to the periphery where housing costs tend to be lower but transport costs are often higher.

US research indicates that housing and transport are two major expenses for most households (CTOD and CNT, 2006; Haas et al., 2006; Lipman, 2006). To cover both needs, 
households make trade-offs by spending more on housing located close to jobs and other facilities in the inner city or choosing more affordable housing in the suburban area with higher commuting cost. Typically, the affordability of housing is measured by relating housing cost to household income. This leads to a perception that renting or buying a house in suburban areas is more affordable. However, any decision on housing location affects a resident's travel behaviour. As commuting cost generally increases with the distance from employment and the city centre, at some point, savings from housing cost are outweighed by increasing transport cost (Isalou et al., 2014; Kellet et al., 2015; Litman, 2014; Mattingly and Morrissey, 2014). Therefore, overall affordability requires affordable housing measured by combined housing and transport expenses.

Previous studies suggested that incorporating transport cost into housing affordability calculations can reveal a different pattern of affordability, particularly in less accessible locations. The spatial configuration of housing stress inside and outside the city centre areas alters when transport costs are included in the calculation. Residential areas with higher transport cost, mostly outside of the city centre, become less affordable (Guerra and Kirschen, 2016; Isalou et al., 2014; Vidyattama et al., 2012). A location's affordability level is associated with proximity to employment centres and other urban services and facilities (Mattingly and Morrissey, 2014; Mulliner et al., 2013) tenureship (Vidyattama et al., 2012) and a household's choice of transport modes (Kellet et al., 2015).

This paper aims to add the literature on the link between housing and transport cost by exploring the effect of transport cost on housing affordability in various combinations of housing type and residential location, in the Bandung Metropolitan Area, Indonesia. This research proposes the data envelopment analysis (DEA) method to examine the affordability of each residential area. Three research questions are posed: (1) How does housing affordability vary due to its location and housing type? (2) How does the measured housing affordability differ when transport cost is incorporated? (3) What are the factors that influence the level of combined housing and transport affordability including their implications for policy? By calculating the overall efficiency using the DEA method, the research shows how transport cost effects vary due to spatial and dwelling characteristics.

The paper is structured into five sections. Section 2 provides a summary of previous studies on combined housing and transport affordability. Section 3 contains the explanation of 
the methods. Section 4 provides the results and discussions. Section 5 presents the conclusions, research limitations and avenues for future research.

\section{Literature Review}

\subsection{Housing Affordability}

The term housing affordability has received considerable attention both in academic and policy debates, yet there is no single agreed definition and measure (Ndubueze, 2007; Nelson et al., 2004; Stone, 2006). Generally, the term depicts the relationship of housing expenses and household income indicated by the maximum amount of income that most likely should be paid by households, both renters and owner-occupants, which does not impose an excessive burden on their incomes (Gabriel et al., 2005). Benchmark values of housing affordability are used to provide meaningful information for policy making internationally. A benchmark for the maximum amount to be spent is generally 25 to $30 \%$ of household income, however, some have proposed higher values. For example, the European Union has an official indicator of "housing costs overburden" as 40\% of income (Eurostat, 2014) and studies in the US and Australia have employed $50 \%$ of income as the "housing stress" benchmark (Gabriel et al., 2005; Kutty, 2005).

However, the need for a broader understanding of housing affordability is also recognised (Gabriel et al., 2005; Haas et al., 2006; Stone, 2006). As Yates and Gabriel (2006) suggest, while a ratio approach is the first step in calculating the cost component of housing affordability, one should proceed with efforts to make such measures more sensitive to other aspects, such as spatial variation. Accordingly, incorporating non-shelter cost in the calculation will provide a greater picture of housing affordability in terms of the trade-offs between housing costs and household consumption of other goods and services, such as transport.

\subsection{Combined Housing and Transport Affordability}

Since the early 1980s, researchers have explored factors that influence housing affordability, particularly transport cost. In the US, research on combined housing and transport burden on working families in 28 metropolitan areas (Haas et al., 2006) showed that transport cost in many areas is as high or higher than housing, and low-income households are more likely to live in high transport cost areas. In order to provide a more comprehensive measure 
of affordability based on location, the Center for Neighborhood Technology (CNT) introduced the Housing+Transportation $(\mathrm{H}+\mathrm{T})$ Affordability Index to incorporate the interaction of housing and transportation costs. CNT has found that $15 \%$ of income is an achievable goal for transport affordability. Combined with $30 \%$ of housing affordability this results in a $45 \%$ benchmark for housing and transport affordability (CTOD and CNT, 2006). In a specific application of the $\mathrm{H}+\mathrm{T}$ Index in the greater Washington DC, they showed that even though housing affordability in an area was predominantly $35 \%$ or less of total household income, when combined with transport cost the combined $\mathrm{H}+\mathrm{T}$ burden rose above $45 \%$ in most areas (CNT, 2010).

The inclusion of a transport component in housing affordability measurement has also emerged outside the US. A number of recent studies have either applied the H+T Affordability Index or modified it based on country or local context. In Australia, a study by Vidyattama et al. (2012) looked not only at capital cities but also in the areas outside in 'balance of state' areas. They found that the impact of transport costs on housing stress is greater for those living in the outside areas than the capital city areas. A recent study in the Melbourne metropolitan area proposed an improved measure of the $\mathrm{H}+\mathrm{T}$ affordability index by using a more detailed estimation of transport costs. Vehicle operational and ownership cost, and public transit usage expenses, for both work and non-work trips, on weekdays and weekend, were used. The results confirm that once transport costs are included, the outer suburbs become less affordable than the inner areas (Saberi et al., 2017). Several studies from European countries provide similar results of the importance of incorporating location to reveal more appropriate measures of housing affordability. In many cases, the location affordability concept is often associated with transport disadvantage and oil vulnerability issue. Using the monocentric model of urban economics, a study in the Paris region examined the effect of transport costs on prudential measures in housing access from the lender's point of view (Coulombel, 2018). The study showed that integrating transport costs within prudential ratios induces households to live in a central area with low $\mathrm{H}+\mathrm{T}$ burdens and protects low-income households' solvency, especially from increased fuel price. Cao and Hickman (2017) developed a composite index to measure car dependence and housing affordability in Greater London to address the vulnerability of neighbourhoods in relation to the rising oil prices and housing prices. The application of the index revealed that the outer suburbs were more vulnerable than other parts of Greater London, due to higher levels of car-dependence, longer distance to work and lower access to public transport, which influenced the overall vulnerability. 
In the developing cities context, the application of $\mathrm{H}+\mathrm{T}$ index has been tested in only few countries. Data availability and variation in context are challenges, which then results in contextual modifications on the concept's application (Guerra and Kirschen, 2016). The CNT's H+T index uses publicly available data to estimate housing and transport costs, which most likely come in different forms in each country, if available. The housing and transport system also vary between countries, even between regions within a country. A study in Qom City, Iran conducted a survey to collect housing and transport costs data to examine the $\mathrm{H}+\mathrm{T}$ affordability. The results indicated that households in the suburban and central area spent $33.9 \%$ and $37.2 \%$ of their income on housing, respectively, which rose to $57.8 \%$ and $44.7 \%$ when transport expenditure was included (Isalou et al., 2014). In Mexico, Guerra and Kirschen (2016) applied the CNT's H+T Index to the Mexico City metropolitan area, but limited the transport analysis to non-driving households, since most households in Mexico city travel by public transit. Using data from household travel survey, the results support the centre-periphery assumption that the inclusion of transport costs flips the geography of affordability. Acolin and Green (2017) added the estimation of owners' housing costs and including both monetary and time costs of commuting to the $\mathrm{H}+\mathrm{T}$ indices in their case study of the Sao Paulo metropolitan region. This study showed that for the lowest income quintile the combined $\mathrm{H}+\mathrm{T}$ burden rose considerably from only $49.4 \%$ to $73.9 \%$ when transport costs are included; for the highest income quintile the increase is insubstantial, from $2.8 \%$ to $2.9 \%$. Together these studies provide evidence that the combined housing and transport affordability concept has potential if applied in other developing countries, including Indonesia, subject to adaptation that is built on local conditions.

Indonesian cities certainly have specific local conditions. Most metropolitan regions feature Indonesia's version of urban sprawl, characterised by leap-frog out-of-sequence development, lower-density housing and a mostly single-use development pattern in newer suburban areas. Many metropolitan regions are monocentric, though Jakarta is so large as to have multiple centres. Urban areas sprawl into their peripheries, where the land is relatively cheap and available to accommodate increasing urban populations. Indonesian cities also have low motorisation rates when compared with American, Australian, European and affluent Asian cities. However, since the 1980s Indonesia has seen rapid motorisation, especially growth in motorcycle use, while public transport use remains low due to poor services (Barter, 2000). The main challenge to applying the $\mathrm{H}+\mathrm{T}$ concept in Indonesia is data availability. Publicly available and accessible data on housing costs, transport costs, and household income, 
is limited. Further discussion on the Indonesian context, particularly the BMA as the case study, and data collection will be explained in the following section.

\section{Methodology}

\subsection{Study Area}

The Bandung Metropolitan Area (BMA) is the largest metropolitan area in the centre of West Java Province, the most populous province in Indonesia. It is located on the main island of the Indonesian archipelago, Java, where the country's population is concentrated. The BMA is only about $140 \mathrm{~km}$ away from Jakarta, the capital city of Indonesia, and its Jabodetabek metropolitan region. Demographically, the BMA's population has been rapidly increasing in recent years. The population of the BMA rose from 6,535,266 in 2000 to 7,977,926 in 2010 (Badan Pusat Statistik, 2010) and 8,737,977 in 2016 (Statistics of Jawa Barat, 2017). Population density in the BMA was the second only to Jakarta, the largest metropolitan area in Indonesia. In 2016, the average population density of the BMA was 6,970 persons $/ \mathrm{km}^{2}$, with a considerable gap between the core area at about 15,000 persons $/ \mathrm{km}^{2}$ and the peripheries at around 1,600 persons $/ \mathrm{km}^{2}$ (Statistics of Jawa Barat, 2017; Statistics of Sumedang, 2017). Population growth has been running from between $1-2$ per cent per annum for many years (Kustiwan et al., 2007) as is not only affected by the natural increase in population but also inmigration due to growth in the services and creative economy sector, with the BMA home to three top-ranked universities in Indonesia.

The escalating of population and economic activity has induced a significant expansion of settlements in suburban areas, spreading along arterial roads within the BMA's territory. Sprawl is indicated by the decreasing population growth rate in the core area, while population growth is increasing - at lower densities - in nearly all subdistricts in the suburban area (Kustiwan, 2010). Over 2010-2015, population in the peripheries increase by $1.4 \%$ per year on average, faster than the core area at 1\% per year (Statistics of Jawa Barat, 2017; Statistics of Sumedang, 2017). The metro spatial plan of the BMA had planned towards a polycentric urban form; yet existing travel patterns shows primacy and monocentricity. Journeys to work, school, and shopping are largely made to Bandung City in the core of the BMA (Kustiwan, 2010). 


\subsubsection{An Overview of Housing and Transport Systems in the BMA, Indonesia}

Indonesian housing is characterised by a high proportion of both owner-occupied and informal houses. According to the Indonesian Bureau of Statistics (BPS), across the nation around $79.61 \%$ of total houses are owner-occupied, and only about $9.52 \%$ were rented in 2017 ; with the remaining $10.87 \%$ categorised as rent-free or official-residence households, where persons occupy family or company housing without paying for rent (Badan Pusat Statistik, $2017 b$ ). By contrast, in 2015, Bandung City in the core of the BMA, had $60.55 \%$ houses owneroccupied and 21.62\% renting (Badan Pusat Statistik, 2017b), as displayed in Figure 1, suggesting a lack of affordable housing product able to be purchased. The lack of access to formal housing finance is a major issue in the Indonesian housing sector. Over $70 \%$ of the total workforce is in the informal sector, mostly low-income, which makes conventional mortgage products inaccessible (Hoek-Smit, 2005; Jones, 2017; Utomo, 2014). Housing mortgage accounts for only $18 \%$ of total housing finance; $70 \%$ of housing purchases involve cash payments (Utomo, 2014). According to Hoek-Smit (2005), self-constructed housing that is managed and financed by individuals (owners) from cash-savings or short-term credit seems to be a common preference in Indonesia. The inability of lower income groups to purchase and access housing in the formal market has made informal or self-help housing an option for the poor. However, residents of informal settlements are in fact, more varied, often being a mix of low- and middle-income people (Tunas and Peresthu, 2010).

A common form of housing in Indonesia is a single-family house (detached or semidetached) with building/land size as minimal as $21 / 60 \mathrm{~m}^{2}$. The trend is towards more multifamily and multi-storey housing, in part due to significantly increased land prices, especially in the inner city areas.

In terms of transportation, the BMA has not kept pace in providing for increasing travel demand. The city as yet has no high capacity public transport systems (rail or exclusive busway) and is dominated by paratransit (Joewono et al., 2016; Syabri et al., 2011). The main paratransit mode, often called angkot, is a minivan with a capacity for 12 seated passengers, privately owned and operated, inadequately regulated and managed, with a relatively low level of service and reliability. In the absence of adequate mass public transit, people in Indonesian major cities are turning towards private vehicles, especially motorcycles, to travel (Sopha and Pamungkas, 2016; Susilo and Joewono, 2017). Over a decade, motorised vehicle ownership has increased substantially. Data from the Indonesian Bureau of Statistics (BPS) shows that 
motorcycle ownership rose by $71 \%$ from 2005 to 2015 , and comprises around $80 \%$ of all registered motorised vehicles (Badan Pusat Statistik, 2017a). In the BMA, the share of motorcycles of the total number of daily trips was 36\% in 2009 (Herwangi et al., 2015) and is believed to have increased substantially since that time. Motorcycles have been seen as an affordable and reliable mode of door-to-door travel that overcome problems of traffic congestion and limited public transit (Susilo et al., 2007). Barter (2000) shows that the middleand low-income countries of Asia (including Indonesia) that have low public transport use tend to have a high preference for motorcycles use. His study also shows that in Indonesian cities, people who travel by private motorised vehicles have shown a greater increase than those who travel by public transport, and there is a drastic drops in the use of non-motorised vehicles (Barter, 2000).

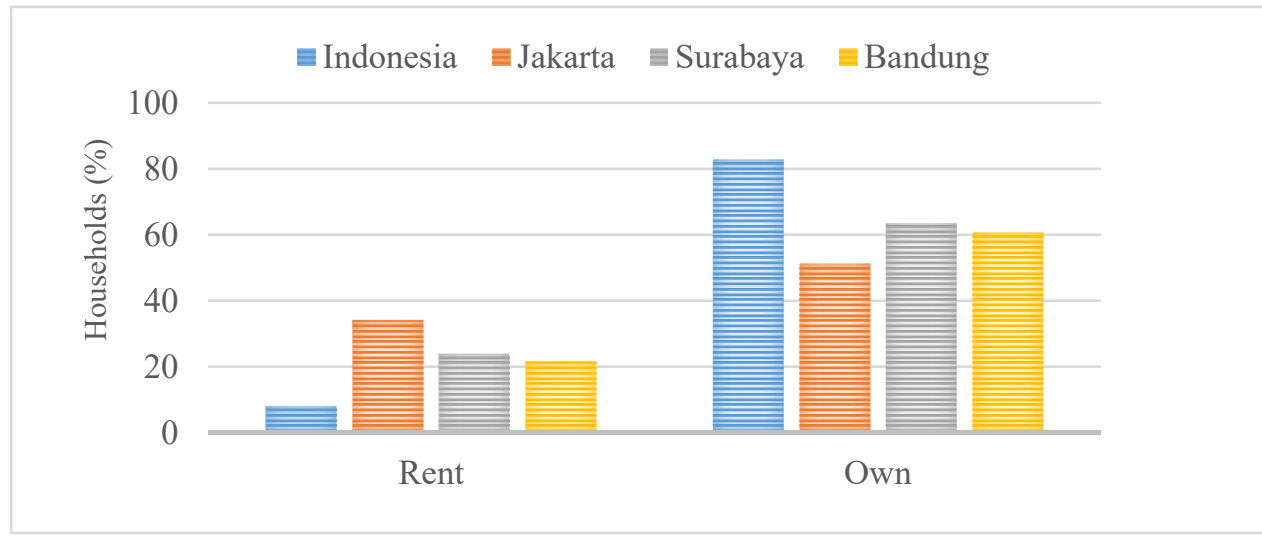

Source: Home Ownership by Province, 2009-2017 (Badan Pusat Statistik, 2017b)

Figure 1. Housing Tenure in Indonesia and Three Largest Cities in Indonesia by 2015

Low road provision is also an issue. As in many other high-density cities in Asia, the quantity of arterial roads per capita in Indonesia is far below that of American, European and Australian cities, whilst the road network density in metre per hectare is actually higher (Barter, 2000). There is a paucity of contemporary arterial and motorway standard roads leaving cities such as the BMA unable to cope with the rapid increase of motorisation, resulting in worsening traffic congestion. The BMA is highly congested, even by Indonesian standards. Bandung City is the 7 th most congested city in Indonesia, with a congestion rate of $14.3 \mathrm{~km} /$ hour and Volume to Capacity (VC) ratio of 0.85 (Widianto, 2014). 


\subsubsection{Survey Design}

The study was designed to capture the patterns of combined housing and transport affordability of middle to low-income groups, across various locations and housing types including informal housing. A survey was conducted in May-June 2016, using questionnaires and face-to-face interviews. These survey times were selected primarily to avoid the holiday season (July and December) in order to have more chance that respondents were available and willing to participate in the survey. The respondents of the survey were aged 18 years and above. All data recorded via the questionnaire was self-reported. The questionnaire consisted of structured questions, divided into four main sections, which captured information on the respondents' demographic and socio-economic profile, housing and transport expenditure, their occupation and income. To control the quality of the data collection process, a trained group of undergraduate student surveyors was recruited and briefed, and ten pilot tests were conducted prior to the survey. Changes were made to the questionnaire based on the pilot to improve the clarity of some questions and ensure more reliable responses.

Nine selected residential areas within the BMA were surveyed, that differed by:

1. Residential density (high, medium, low), defined as the ratio of the number of dwellings to the total built-up area in a sub-district. High residential density areas were categorised as $>$ 40 dwellings/ha, medium density as 30-40 dwellings/ha, and low density as less than 30 dwellings/ha.

2. Distance from the city centre (see Figure 2): categorised as $0-5 \mathrm{~km}$ (city core), 5-10 km (mid-suburban), and $>10 \mathrm{~km}$ (outer suburban). The city centre refers to the central business district in the Alun-alun (main city square) area, where major employment and commercial centres are located.

3. Housing type: apartment (medium and high rise) and non-apartment (detached, semidetached and townhouse).

4. The type of development: formal housing refers to residential estates initiated and built by a developer and/or government; informal housing refers to self-help housing, initiated and constructed by individual or group of household. Formal housing is usually more expensive and generally is inaccessible to the very poor households, where the informal sector may be their only option. 
The survey aimed to focus on middle-to low-income households. In terms of income, the criteria often used in Indonesia to define the middle- to low- income groups is one developed by Asian Development Bank (2010), which is per capita income/consumption equal or less than US \$20 per day. For this study, it is assumed that these households were living in the middle- to low-income housing. Therefore, the selected neighbourhoods are limited to residential sites that meet the criteria of the middle- to the low-income housing (namely Rumah Menengah and Rumah Sederhana) indicated by prices/rents, dwelling size, and type. In the selection process, dwelling size and type of multi-storey houses were used. The single-family houses (non-apartment) included only those with building sizes ranged from $21 \mathrm{~m}^{2}$ to $90 \mathrm{~m}^{2}$ (Suparno and Marlina, 2007) and the multi-family dwellings (apartments) included only the middle- to low-income multi-storeys housing known as RUSUNAWA (low-cost rental apartment) and RUSUNAMI (low-cost owned apartment).

Site selection began with grouping all sub-districts within the BMA into high, medium and low residential densities. Then, one sub-district with high residential density located within 0-5 km from the city centre was randomly selected. Similar processes were applied to select a medium density sub-district within 5-10 km distance and low-density sub-district in an area of more than $10 \mathrm{~km}$ from CBD. Next, in each selected sub-districts one residential site of each housing type (single/multi-family house, formal/informal, high/medium/low rise) was randomly selected. For formal houses, the selection was made from the lists of middle- to lowincome class housing sites, which were obtained from the provincial and local government offices in the BMA. For informal houses, selected survey sites were those with a similar range of dwelling size located nearby the selected formal housing sites. The results were nine housing sites within the BMA as presented in Table 1. 
Table 1. Selected Survey Sites in the Bandung Metropolitan Area, Indonesia

\begin{tabular}{|c|c|c|c|c|c|c|c|}
\hline \multirow[t]{2}{*}{ Selected Survey Sites } & \multirow{2}{*}{$\begin{array}{l}\text { Residential } \\
\text { Density }\end{array}$} & \multirow{2}{*}{$\begin{array}{l}\text { Distance from } \\
\text { City Centre }\end{array}$} & \multirow[t]{2}{*}{ Form } & \multirow{2}{*}{$\begin{array}{l}\text { Development } \\
\text { Type }\end{array}$} & \multirow{2}{*}{$\begin{array}{c}\text { Average } \\
\text { Household } \\
\text { Size }\end{array}$} & \multicolumn{2}{|c|}{ Tenure } \\
\hline & & & & & & Owned & Rented \\
\hline $\begin{array}{l}\text { Location } 1 \\
\text { (Gateway Apartment) }\end{array}$ & High & $\begin{array}{l}0-5 \mathrm{~km} \\
\text { (city core) }\end{array}$ & $\begin{array}{l}\text { High } \\
\text { Rise }\end{array}$ & $\begin{array}{c}\text { Formal Private } \\
\text { Developer }\end{array}$ & 2.94 & $81 \%$ & $19 \%$ \\
\hline $\begin{array}{l}\text { Location } 2 \\
\text { (Bumi Asri III) }\end{array}$ & High & $\begin{array}{c}0-5 \mathrm{~km} \\
\text { (city core) }\end{array}$ & $\begin{array}{l}\text { Low } \\
\text { Rise }\end{array}$ & $\begin{array}{c}\text { Formal Private } \\
\text { Developer }\end{array}$ & 3.87 & $86 \%$ & $14 \%$ \\
\hline $\begin{array}{l}\text { Location } 3 \\
\text { (Cicadas) }\end{array}$ & High & $\begin{array}{c}0-5 \mathrm{~km} \\
\text { (city core) }\end{array}$ & $\begin{array}{l}\text { Low } \\
\text { Rise }\end{array}$ & Informal Self-help & 4.78 & $74 \%$ & $26 \%$ \\
\hline $\begin{array}{l}\text { Location } 4 \\
\text { (Rusunawa Unpas) }\end{array}$ & Medium & $\begin{array}{c}>5-10 \mathrm{~km} \\
\text { (mid-suburban) }\end{array}$ & $\begin{array}{l}\text { Medium } \\
\text { Rise }\end{array}$ & $\begin{array}{l}\text { Formal Public } \\
\text { Rental }\end{array}$ & 3.02 & - & $100 \%$ \\
\hline $\begin{array}{l}\text { Location } 5 \\
\text { (Pesona Ciwastra Permai) }\end{array}$ & Medium & $\begin{array}{c}>5-10 \mathrm{~km} \\
\text { (mid-suburban) }\end{array}$ & $\begin{array}{l}\text { Low } \\
\text { Rise }\end{array}$ & $\begin{array}{c}\text { Formal Private } \\
\text { Developer }\end{array}$ & 4.02 & $84 \%$ & $16 \%$ \\
\hline $\begin{array}{l}\text { Location } 6 \\
\text { (Rancasawo) }\end{array}$ & Medium & $\begin{array}{c}>5-10 \mathrm{~km} \\
\text { (mid-suburban) }\end{array}$ & $\begin{array}{l}\text { Low } \\
\text { Rise }\end{array}$ & Informal Self-help & 5.43 & $81 \%$ & $19 \%$ \\
\hline $\begin{array}{l}\text { Location } 7 \\
\text { (Rusunawa Batujajar) }\end{array}$ & Low & $\begin{array}{l}>10 \mathrm{~km} \\
\text { (outer suburban) }\end{array}$ & $\begin{array}{l}\text { Medium } \\
\text { Rise }\end{array}$ & $\begin{array}{l}\text { Formal Public } \\
\text { Rental }\end{array}$ & 2.96 & - & $100 \%$ \\
\hline $\begin{array}{l}\text { Location } 8 \\
\text { (Puri Indah Lestari) }\end{array}$ & Low & $\begin{array}{c}>10 \mathrm{~km} \\
\text { (outer suburban) }\end{array}$ & $\begin{array}{l}\text { Low } \\
\text { Rise }\end{array}$ & $\begin{array}{c}\text { Formal Private } \\
\text { Developer }\end{array}$ & 4.20 & $95 \%$ & $5 \%$ \\
\hline $\begin{array}{l}\text { Location } 9 \\
\text { (Batujajar Timur) }\end{array}$ & Low & $\begin{array}{c}>10 \mathrm{~km} \\
\text { (outer suburban) }\end{array}$ & $\begin{array}{l}\text { Low } \\
\text { Rise }\end{array}$ & Informal Self-help & 4.33 & $100 \%$ & - \\
\hline
\end{tabular}


We surveyed three locations of the multi-family housing type (locations 1, 4 and 7). Location 1, Gateway Apartment, was built by a private developer under a national government program with objectives including providing affordable multi-family housing for middle- to low-income home-buyers (RUSUNAMI). It comprises two towers of 16 storey apartments, and by the time of the survey only around $70 \%$ of the 1,305 units were occupied. Locations 4 and 7 are multi-storey low-income rental dwellings built by the government known as RUSUNAWA, targeted at the poor who cannot access the formal housing market. Both of these locations are medium-rise apartments of five storeys. Rusunawa UNPAS (location 4) had a total of 98 units, all were occupied by four students in each unit, while Rusunawa Batujajar (location 7) had a total of 97 units, with only 78 units occupied.

Locations 3, 6 and 9 are all informal housing or the so called 'kampung'. Referring to Ford's model of Indonesian kampung (see Tunas \& Peresthu, 2010) location 3 represents an inner city kampung where its central location provides access to employment and economic activity; it has high density but within small one or two-storey houses attached to each other or with only a small space between them. Within the settlement there is poor urban infrastructure and few services, and some have no legal tenure. Informal settlements in location 6 are midcity kampung, located between the formal residential areas in the middle-suburbs. It has a substantially lower density, mostly has legal land ownership and was built in a designated residential area, thus has better services than the inner city kampung. Location 9 is a rural kampung, which originated as a rural settlement that was gradually surrounded by urban development. This rural kampung is distinguished by its low density, detached housing type, and rural lifestyle influences. All of these informal housing survey sites were located close to one of the formal housing sites and encompassed about 4 to 7 Rukun Tetangga (RT), the smallest administrative unit in Indonesia, where an urban RT generally consists of around 3050 households.

The remaining three locations $(2,5$ and 8$)$ are formal single-family residential estates, built by private developers. There were 224, 185 and 768 units occupied by households in locations 2, 5, and 8, respectively. In Indonesia, formal housing is usually more expensive than informal housing given the same type and location. So it is with these three locations. It has been argued that among other factors, high development permit and land registration costs play a role in this housing cost disparity (Monkkonen, 2013). The locations are shown in Figure 2. 
A total of 405 questionnaires were collected across the selected residential areas. The data collection was a mix of systematic random sampling and snowball sampling, due to the difference in the level of access granted to conduct the survey. For example, in Gateway Apartment (location 1), the property management refused to provide access for "door-to-door" contacts. They only allowed survey staff to approach potential respondents in the public areas such as at the swimming pool and food court and provided a contact person who could refer the survey to potential respondents.

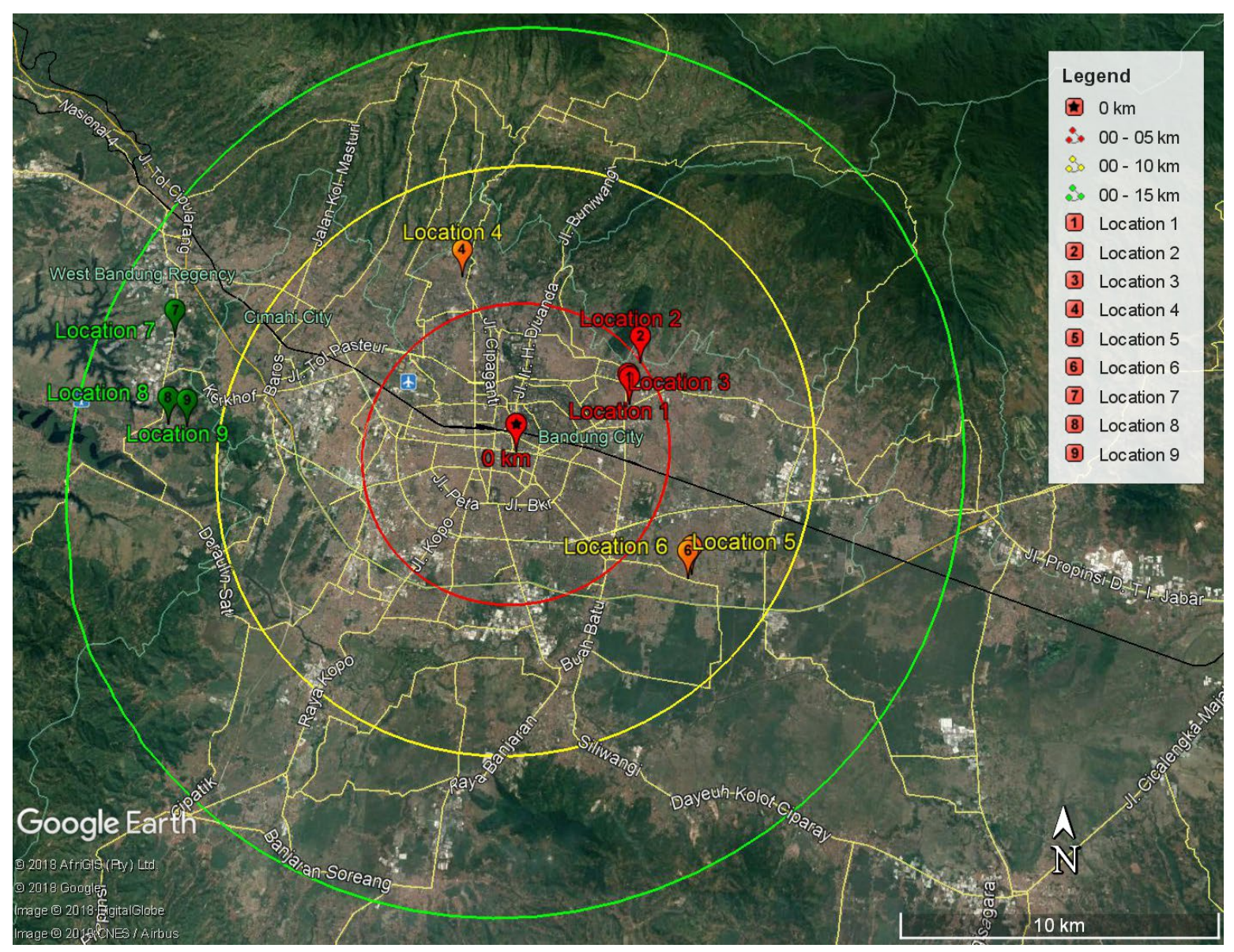

Figure 2. Selected Housing Locations in the BMA, Indonesia ${ }^{1}$

\subsection{Data and Variables}

The survey captured data on three variables: transport cost, housing cost, and household income.

The $0 \mathrm{~km}$ refers to the historical $0 \mathrm{~km}$ point located in the Asia Afrika road in the CBD of Bandung City, ${ }^{1}$ which was the mark of the initial development of the modern Bandung City that started with the construction of the Great Post Road (today Asia-Afrika Road) 


\subsubsection{Transport Cost}

Transport cost in this paper comprised monthly household expenses on daily travel to main travel purposes including travel to work, school, and shopping, for private vehicles and public transit modes. Travel for recreation and other purposes (i.e. long-distance travel such as air-travel and inter-city or inter-province travel) was excluded to limit this research to daily travel made by households. The limitation arising from not including all types of travel is that households with a distinctive type of travel, such as those who have retired or households with a family member that needs regular travel to health facilities, could not be covered. The private transport cost variable was calculated from the operational cost of private vehicle users including fuel, parking fees, maintenance cost and insurance. The purchase cost of a motor vehicle was excluded due to the potential bias it might have, as the higher income households tend to own cars rather than motorbikes or to own more than one vehicle, which is common in Indonesian cities. The public transport cost data was collected from the estimated monthly expenses for all public transport modes used by the household including bus, train, mini-van (angkot), taxi and motorcycle-taxi (ojek).

\subsubsection{Housing Cost}

Housing costs were defined as the monthly expenses of the household for their accommodation. This refers to rent for renters and "owner equivalent rent" for owners, added to regular operational costs including electricity, water and gas rates, body corporate fees or neighbourhood maintenance fees, and property tax. Repair and maintenance costs were excluded from the calculation for being a non-regular cost and greatly depended on the existing condition and quality of houses.

The owners' equivalent rent (OER) is a proxy for housing cost of owner-occupants, which has been used by the Indonesian Bureau of Statistics for National Socio-Economic Survey (SUSENAS), the US Bureau of Labor Statistics in constructing the Consumption Price Index (Hill et al., 2017; Poole et al., 2005) and has also been used in housing affordability studies (Acolin and Green, 2017). This approach is based on the estimated rent that owneroccupants would fetch in the competitive market for their house, which can be calculated by asking owners how much they presume their unit would rent for in the market (Acolin and Green, 2017; Hill et al., 2017). Given the characteristics of housing tenure and housing finance mechanisms in the Indonesian context (high owner-occupied and informal housing rates, cash 
payment preferences to acquire houses) the use of owners' equivalent rents rather than mortgage payments is more suitable to cover all the housing types in the study area. Although the use of OER may be less appropriate to estimate the cost burden of an owner-occupied household, since it is not an actual cost and is at times difficult for respondents to accurately provide, it can be more helpful in evaluating the affordability of specific housing locations where such figures can be aggregated and ground-truthed, as in this study, as opposed to evaluating various groups of households spread across an urban area. However, using the OER as a proxy for the cost of housing, particularly when information drawn from owner's estimation, holds a number of limitations. It has been suggested that owners value their property higher than renters (Heston and Nakamura, 2009), and they may not be well-informed because they are not actively involved in the rental market (Hill et al., 2017).

\subsubsection{Household Income}

Monthly household net income was generated from the questionnaire data. The net income refers to a household's gross income subtracted from their personal income tax. In Indonesia, published data on households' income is not available. Enquiry about income is considered culturally sensitive, thus reliable data is often difficult to obtain. This study collected household income data by asking households to report their income in specific ranges, which was then assigned an imputed median value. This loss of information on actual income is a limitation of the dataset.

\subsubsection{Summary Values}

Of the survey respondents, $77.4 \%$ were women and $26.7 \%$ were men. In all locations, most of them were married couples (79.5\%), except in the student accommodation (location 4), where respondents were all single. Of respondents, $19.8 \%$ were aged less than 25 years, $58.3 \%$ were in the age range of $25-50$ years, and $22.0 \%$ were in the age group of over 50 years. Predominantly, the respondent's household size was 3 to 5 people (74.3\%), followed by 1 to 2 people $(13.3 \%)$, and more than 5 people $(12.3 \%)$. Regarding highest education, $10.6 \%$ had elementary, 59.6\% had secondary, and $29.7 \%$ had tertiary education. Those who only had elementary education were all living in the informal settlements (locations 3,6, and 9). Whilst the respondents from the informal housing sites tended to have bigger household sizes, respondents in the public rental houses had no reported household size in the ' 5 or more' category because of maximum occupancy rules in such locations. 
The socio-demographic statistics of the sample fairly represent the general population of the BMA, that according to the latest census data (2010) characterised by around $51 \%$ of the population being aged $25-50$ years, $55 \%$ of the population having secondary level education, and household sizes on average of about 4 people (Badan Pusat Statistik, 2010). The only exception is the highly unbalanced gender proportion in the sample with sex ratio of 2.9 compared to 1.03 for the BMA (Badan Pusat Statistik, 2010) which likely reflects the gendered response within households as to who would complete the survey questionnaire. However, this should not affect the validity of the responses used in this study, partly because the survey focused on expenditure and income of household not individual, and women are commonly thought to have better knowledge of a household's budget, at least in the Indonesian context.

After cleaning the data, three data records were removed due to missing data on income. Table 2 displays the maximum, minimum, average, and standard deviation values for all the variables for each residential location. Data shows that housing cost in location 1, the lowincome apartment is the most expensive, followed by locations 2 and 5 . All are formal housing with proximity to the CBD. Private and public transport costs present a great variation in value and pattern, but location 1 constantly has the highest expenses on both while location 4 is the lowest. Location 4 has similar values for all minimum, average, and maximum values of housing costs. The single-controlled rent price, in which rental price includes operational costs such as water and electricity, applied to public rental housing in this location.

\subsection{Method and Analysis}

\subsubsection{Affordability Data Envelopment Analysis (DEA)}

Studies examining housing and transport affordability generally apply the price or cost to income ratio model which presents the housing and transport expenses as a proportion of a given area or a household unit's income. This proportion is then compared to the internationally applied or locally set benchmark ranging from 25 to 50\% for housing (Eurostat, 2014; Gabriel et al., 2005; Jewkes and Delgadillo, 2010; Kutty, 2005) and 10 to 20\% for transport (CNT, 2010; Venter and Behrens, 2005). Although there is no fixed single standard, the most popular is the $30 \%$ of income spent on housing and $15 \%$ on transport, or $45 \%$ maximum of income spent on both expenses (CTOD and CNT, 2006; Isalou et al., 2014). 
Table 2. Summary Values of All Variables for each Housing Location in the BMA (in thousands of rupiah)

\begin{tabular}{|c|c|c|c|c|c|c|c|c|c|}
\hline Variables & $\begin{array}{c}\text { Location } \\
\begin{array}{c}1 \\
\mathbf{N}=\mathbf{3 0}\end{array}\end{array}$ & $\begin{array}{c}\text { Location } \\
\qquad \begin{array}{c}2 \\
N=44\end{array}\end{array}$ & $\begin{array}{c}\text { Location } \\
\begin{array}{c}3 \\
N=46\end{array} \\
\end{array}$ & $\begin{array}{c}\text { Location } \\
4 \\
\mathrm{~N}=44\end{array}$ & $\begin{array}{c}\text { Location } \\
\begin{array}{c}5 \\
N=45\end{array}\end{array}$ & $\begin{array}{c}\text { Location } \\
\qquad \begin{array}{c}6 \\
N=43\end{array}\end{array}$ & $\begin{array}{c}\text { Location } \\
\begin{array}{c}7 \\
\mathrm{~N}=48\end{array}\end{array}$ & $\begin{array}{c}\text { Location } \\
\quad 8 \\
\mathrm{~N}=44\end{array}$ & $\begin{array}{c}\text { Location } \\
9 \\
\mathrm{~N}=\mathbf{5 8}\end{array}$ \\
\hline \multicolumn{10}{|c|}{ Housing Cost } \\
\hline Minimum & 2,505 & 1,397 & 298 & 292 & 1,112 & 228 & 308 & 409 & 245 \\
\hline Maximum & 9,478 & 9,210 & 7,103 & 292 & 8,929 & 7,278 & 509 & 1,325 & 1,734 \\
\hline Mean & 5,350 & 3,036 & 1,524 & 292 & 2,403 & 1,178 & 387 & 900 & 664 \\
\hline Std. Dev & 1,986 & 1,500 & 1,370 & 0 & 1,611 & 1,425 & 46 & 224 & 277 \\
\hline Skewness & 0.43 & 2.07 & 2.50 & - & 3.40 & 3.54 & 0.65 & -0.21 & 1.07 \\
\hline Kurtosis & -0.79 & 5.72 & 6.73 & - & 11.88 & 12.77 & -0.03 & -0.72 & 2.79 \\
\hline \multicolumn{10}{|c|}{ Private Transport Cost } \\
\hline Minimum & 200 & 53 & 80 & 40 & 100 & 47 & 70 & 58 & 49 \\
\hline Maximum & 2,560 & 2,550 & 558 & 250 & 6,392 & 967 & 625 & 3,000 & 1,167 \\
\hline Mean & 982 & 816 & 243 & 108 & 1,140 & 269 & 244 & 438 & 250 \\
\hline Std. Dev & 523 & 725 & 118 & 82 & 1,144 & 206 & 150 & 525 & 220 \\
\hline Skewness & 1.30 & 1.07 & 1.09 & 1.87 & 3.12 & 1.61 & 0.81 & 3.38 & 2.44 \\
\hline Kurtosis & 2.16 & 0.39 & 1.11 & 3.81 & 12.28 & 3.47 & -0.14 & 14.10 & 7.07 \\
\hline \multicolumn{10}{|c|}{ Public Transport Cost } \\
\hline Minimum & 15 & 15 & 8 & 4 & 20 & 4 & 16 & 16 & 20 \\
\hline Maximum & 3,000 & 1,200 & 800 & 108 & 1,000 & 600 & 500 & 1,200 & 560 \\
\hline Mean & 427 & 294 & 195 & 31 & 181 & 78 & 149 & 144 & 165 \\
\hline Std. Dev & 715 & 334 & 203 & 27 & 242 & 111 & 136 & 239 & 146 \\
\hline Skewness & 3.50 & 1.65 & 1.69 & 1.75 & 2.30 & 3.54 & 1.22 & 3.68 & 1.35 \\
\hline Kurtosis & 13.04 & 2.17 & 2.37 & 2.31 & 5.07 & 14.38 & 0.81 & 15.03 & 1.07 \\
\hline \multicolumn{10}{|c|}{ Household Net Income } \\
\hline Minimum & 2,250 & 750 & 750 & 750 & 750 & 750 & 750 & 750 & 750 \\
\hline Maximum & 6,000 & 6,000 & 5,250 & 3,750 & 6,000 & 6,000 & 5,250 & 6,000 & 5,250 \\
\hline Mean & 5,275 & 4,364 & 2,446 & 1,330 & 4,650 & 1,570 & 2,094 & 2,932 & 1,836 \\
\hline Std. Dev & 1,222 & 1,867 & 1,327 & 927 & 1,666 & 1,480 & 888 & 1,793 & 1,312 \\
\hline Skewness & -1.39 & -0.92 & -0.54 & 1.38 & -1.12 & 2.07 & 0.66 & 0.41 & 1.23 \\
\hline Kurtosis & 0.58 & -0.53 & -0.23 & 0.91 & 0.22 & 3.73 & 2.80 & -0.96 & 1.03 \\
\hline
\end{tabular}

Note: the maximum, minimum and average values are in Indonesian Rupiah (IDR); 1 USD = 13,529.48 IDR (2017).

This paper proposes a new approach to measure and rank housing and transport affordability by using the Data Envelopment Analysis (DEA) method. DEA is a non-parametric efficiency measurement method originally designed to evaluate the relative efficiency of a decision making unit (DMU) in an organisation or between organisations in the same industry performing similar tasks (Chiou et al., 2012). The main reason to choose the DEA approach is to generate indices without subjectively setting any weight. A simple expenditure to income ratio is actually given an equal weight setting to both expenditure and income. In terms of the 
DEA approach, it is a non-parametric method that allows DMUs (locations in this study) to rank themselves in the best way without given any prior weight to any variable. In other words, if a particular DMU does not have ideal indices (affordability in this study), it means there must be a major issue(s) for this particular DMU. DEA employs linear programming tools to estimate an efficiency frontier and the best performing DMU/s that would be used as a benchmark to measure the relative performance of all DMUs being observed. The position of DMUs to the benchmark determines their efficiency scores, with only DMUs on the frontier line considered as efficient (efficiency score $=1.00)$, while those below the line $(0 \leq$ efficiency score $<1)$ are inefficient.

Since the initial model of DEA introduced by Charnes, Cooper, and Rhodes (1978), widespread acceptance and uses of the method have been recognized in many fields (Bowlin, 1998; Seiford and Thrall, 1990). The approach has been applied in a variety of practices including public health (Helmig and Lapsley, 2001; Kao and Hwang, 2008; Kirigia et al., 2002), education (Abbott and Doucouliagos, 2003; Thanassoulis et al., 2011), and finance (Avkiran, 2011; Halkos and Salamouris, 2004; Zhao and Yue, 2010). In the transport sector, DEA approaches have been used extensively to evaluate the efficiency of different practices, such as airlines (Adler and Golany, 2001; Chiou and Chen, 2006), airports (Martín and Román, 2006; Sarkis, 2000), public transport (Karlaftis, 2004; Sheth et al., 2007) and recently in oil vulnerability benchmarking (Leung et al., 2016). In the housing sector, a more limited use of the DEA approach has been applied to evaluate the performance of housing policy ( $\mathrm{Li}$ and $\mathrm{Xu}$, 2016), as well as housing industry and property management (Avkiran, 2006; Juan, 2009; Sepehrdoust, 2011).

By using the DEA model, this study examined the performance in terms of affordability (labeled as 'efficiency' in a DEA framework) of the nine residential areas to capture the effect of transport costs on housing affordability in various spatial settings and housing types. Thus, the model proposed in this paper treats each housing location (1-9) as DMUs and the efficiency measure as affordability. For the calculation, data for each input and output variables were generated from the survey data by aggregating the household level data into the neighbourhood (location) level using the mean values. The evaluation results will then indicate which location is 'efficient' or in this case, affordable. A great variation between households may be hidden by this aggregate values and limit this study from capturing the variation of households' expenditure and income within each location. 
The first widely applied DEA model, the Charnes, Cooper, Rhodes (CCR) version, which had an input orientation and assumed a constant return to scale, is used. This model can be expressed by:

$$
\begin{gathered}
\text { [CCR] } \underset{u, v}{\operatorname{Max}} h_{q}=\sum_{r=1}^{R} u_{r} y_{q r} \\
\text { s.t. } \quad \sum_{r=1}^{R} u_{r} y_{i r}-\sum_{j=1}^{J} v_{j} x_{i j} \leq 0, i=1,2, \cdots, I \\
\sum_{j=1}^{J} v_{j} x_{s q}=1 \\
v_{j} \geq 0, j=1,2, \cdots, J \\
u_{r} \geq 0, \\
r=1,2, \cdots, R
\end{gathered}
$$

where $h_{q}$ is the affordability score of location $q$. Supposed that there are in total $I$ locations to be evaluated, each of which has $J$ types of inputs and $R$ kinds of outputs. $y$ and $x$ are the observed DMU's output and input values, while $u_{r}$ and $v_{j}$ are the multipliers corresponding to output $r$ and input $j$ of location $q$, respectively. From the above CCR model, the optimal input/output multipliers can be determined.

The advantage of the DEA method is that it offers a more objective way to measure affordability and set affordability benchmark. The DEA approach does not require a prior settings or assumptions of the relationships between the input and output variables (i.e. weights), as has been done in some affordability measurement methods (CNT, 2010; Ndubueze, 2007). The optimal weights for both inputs and outputs are assigned during the calculation based on the observed data, and unique for each DMU (Cooper et al., 2007; Leung et al., 2016). Furthermore, concerns around defining a suitable benchmark to be applied across any geographical and socio-demographical entities have been a continuing debate in the housing and transport affordability literature (Bramley, 2012; Gomez-Lobo, 2011; Venter and Behrens, 2005). Setting up a benchmark is important not only for inter countries, regions, cities, or even household groups comparison, but also for the implications for housing and transport policy, e.g. in priority setting for improving affordability level of an area or household groups. In DEA calculation, each DMU (in this case, residential location) is being compared to each 
other to measure the relative efficiency. Thus, DMUs with the best combination of inputs and outputs (score of 1.00) are the most affordable locations relative to other locations included in the observation. The best performing DMUs will generate the frontier line and set as the benchmark to directly rank the affordability level of other locations in the observation. As the benchmark, these DMUs set as the reference (peer) for other non-efficient DMUs to improve their performance.

Referring to the relevant literature on location affordability (CTOD and CNT, 2006; Haas et al., 2016; Haas et al., 2006; Isalou et al., 2014; Mattingly and Morrissey, 2014; Vidyattama et al., 2012), we use housing cost, private transport cost and public transport cost as the input variables and household net income as the output variable. The measure of the ratio of output variable over all input variables is calculated to find such values for $u$ and $v$ that the affordability measure of $i$-th location is maximised, subject to constraints that the efficiency or affordability value would be between 0 and 1 . Three DEA models were calculated in this study:

1. Housing Affordability

This model calculated housing affordability with one input variable (average housing expenditure) and one output variable (average net household income).

2. Transport Affordability

The second model calculated the transport affordability alone with two input variables: the average of private vehicle transport cost and the average of public transport cost. These two variables were selected to capture the effect of private and public transport cost on the overall affordability of transport. While the output variable is the same as the previous model, that is the average of net household income.

3. Combined Housing and Transport $(\mathrm{H}+\mathrm{T})$ Affordability

To account for the effect of transport cost on housing affordability, the third model calculated the combined housing and transport affordability. There are three input variables here: housing cost, private vehicle transport cost, and public transport cost. Output variable still is net household income.

For DEA modeling, it has been consistently suggested in the literature that there should be sufficient numbers of observations (n) in comparison with the number of factors. Golany and Roll (1989) suggested that $\mathrm{n}$ should be greater than $2 \times$ (input number $(\mathcal{S})$ +output number $(R))$, whereas Banker et al. (1989), Friedman and Sinuany-Stern (1998) and Cooper et al. (2007) proposed that it should be greater than $3 \times(J+R)$. Dyson et al. (2001) recommended that $\mathrm{n}$ should 
be greater than $2 \times J \times R$. There are 9 observations in this study, suggesting that the models meet at least two criteria for the DEA modeling. However, a small number of DMU may result in overestimation of efficiency, where an excessive number of DMU being observed considered as efficient due to the inadequate number of degrees of freedom (Alirezaee et al., 1998; Bowlin, 1998).

Application of DEA requires the functions relating inputs to outputs have the mathematical property called isotonicity (Banker et al., 1989; Bowlin, 1998; Charnes et al., 1985), which means that an increase in any input should result in an increase in output, or having a positive correlation. Table 3 displays the correlation coefficients among housing and transport cost variables and household income variable. Note that all correlation coefficients are significantly positive, suggesting that the dataset satisfies the isotonicity property. The positive correlation suggests that any differences in household net income between locations are likely to affect differences in housing and transport expenditures.

Table 3. Correlation Coefficients among Input and Output Variables

\begin{tabular}{lcccc}
\hline \multirow{2}{*}{ Variable } & Output & \multicolumn{3}{c}{ Input } \\
\cline { 2 - 5 } & Net income & $\begin{array}{c}\text { Housing } \\
\text { Cost }\end{array}$ & $\begin{array}{c}\text { Public Transport } \\
\text { Cost }\end{array}$ & $\begin{array}{c}\text { Private } \\
\text { Transport Cost }\end{array}$ \\
\hline Net income & 1.00 & & & \\
Housing Cost & 0.89 & 1.00 & 1.00 & 1.00 \\
Public Transport Cost & 0.85 & 0.92 & 0.70 & 1 \\
Private Transport Cost & 0.96 & 0.81 & & \\
\hline
\end{tabular}

To further analyses the DEA affordability results, Tobit regression modelling was used to identify external factors affecting the DEA results of $\mathrm{H}+\mathrm{T}$ affordability in the BMA. The Tobit model, also known as a censored regression model, is often used to further analyse DEA results (Merkert and Hensher, 2011; Mujasi et al., 2016) because it is designed to estimate linear relationships between variables with a censored dependent variable. In this research, the tobit regression is not a completely independent analysis, which is the next stage of the DEA analysis, hence the number of observation limited to the results of the DEA models, which is 9 observations. Having a very small number of observations to conduct regression analysis raised a great concern about statistical power and estimation accuracy. There are several rules of thumb about minimum sample size requirement for various regression analysis, around 1020 subjects per variable (Harrell, 2001; Peduzzi et al., 1996; Schmidt, 1971), but a recent study by Austin and Steyerberg (2015) argued that a minimum number of 2 subjects per predictor 
variables is needed for logistic regression. This research only has 1.8 subjects per predictor variables, slightly below the minimum requirement. Thus, caution must be applied in the interpretation of results. The results should be taken as explorative, needing to be confirmed in future research.

Based on the literature and available data and information, we chose the following five factors that might have impacts on housing and transport cost as the explanatory variables: high-rise housing $(H R)$, informal housing $(I F)$, distance from the city centre $(D I)$, direct access to main roads $(M R)$, and motorcycle ownership $(M O)$. Where $H R$ is a binary variable representing whether the housing structure is a high-rise building with more than 8 storeys. The type of housing structure affects housing prices and affordability (Aurand, 2010; Carlson and Mathur, 2004). A positive sign is expected, as high-rise housing most likely has higher density and use less land, thus are more affordable than the low-rise, low-density, and land-intensive single-family house. $I F$ is a binary variable indicating that the house developed in an informal way such as via self-help housing, or built by a developer or formal housing. In many developing countries, informal housing has become an option for the poor to afford housing (Arnott, 2008; Tunas and Peresthu, 2010), so a positive sign is expected. The following two explanatory factors $(D I$ and $M R)$ are related to residential location. The location theory suggested that higher price is often associated with higher accessibility. $D I$ is a continuous variable, defined as the Euclidean distance of the settlements from the city center in a kilometre. The greater distance is anticipated to have higher transport cost, which often offset the savings from lower housing costs, and lower the combined $\mathrm{H}+\mathrm{T}$ affordability (a negative sign is expected). $M R$ is a binary variable indicating that the residential areas are located by or have direct access to main roads or not. Housing sites by the main roads are assumed to be more expensive due to an economic and strategic value which made the land price higher (a negative sign is expected). This relates to the limited road space in Indonesian cities and the considerable mobility benefits that access to the small number of arterial road corridors provides. The last factor, $M O$, is also a continuous variable, defined as the percentage of motorcycle ownership in each residential area observed. In 2010, the share of motorcycle ownership was $72 \%$, while car was only 25\% (Susilo and Joewono, 2017). A study by Nasruddin and Ratnasari (2014) which compared the operational costs (including the value of time) between motorcycles and public transport incurred by students to commute to their university, showed that on average, motorcycles cost $56 \%$ less than public transport. So, it is assumed that areas with high 
motorcycle ownership rates would be better off in terms of transport affordability (positive sign is expected).

\section{Results and Discussions}

\subsection{Housing, Transport, and Combined H+T Affordability}

The DEA affordability scores for housing, transport and combined $\mathrm{H}+\mathrm{T}$ for the nine housing locations are presented in Table 4. Note that only one location is evaluated as efficient for each housing and transport affordability model (locations 7 and 4), and both become the locations that are deemed efficient when the housing and transport costs are combined $(\mathrm{H}+\mathrm{T}$ affordability). Generally, efficiency scores for transport are higher than that of housing and greatly influenced the overall affordability scores (see DEA scores for locations 1-6); the impact of transport cost on the combined $\mathrm{H}+\mathrm{T}$ affordability is significant.

In addition, we included the affordability index from the simple cost/income ratio method next to the DEA scores in Tables 4 and 5. The interpretation focuses only in relation to the comparison with the DEA scores. In some cases, the results show that the housing and transport expenses are exceptionally high compared to households' income, which is likely to be related to the limitation of households' income data (use of a range instead of actual income) and the fact that most of households are homeowners, thus the reported housing costs are actually opportunity costs. In general, both the DEA and cost/income ratio method deliver quite similar results with locations 4 and 7 as the most affordable for the combined $\mathrm{H}+\mathrm{T}$ affordability.

Based on the affordability scores, the residential areas were ranked from the most affordable to the least affordable as displayed in Table 5. For the DEA approach, the housing affordability model shows that households living in the outer suburban areas experienced the lower financial burden of housing costs as housing expenditure broadly declines with distance from the city centre. As a result, the affordability scores and ranking show that households located in outlying areas (locations 7, 8, and 9) are more affordable compared to the others. Land price is likely to play a significant role in these lower housing prices. 
Table 4. Affordability Scores for each Housing Location in the BMA

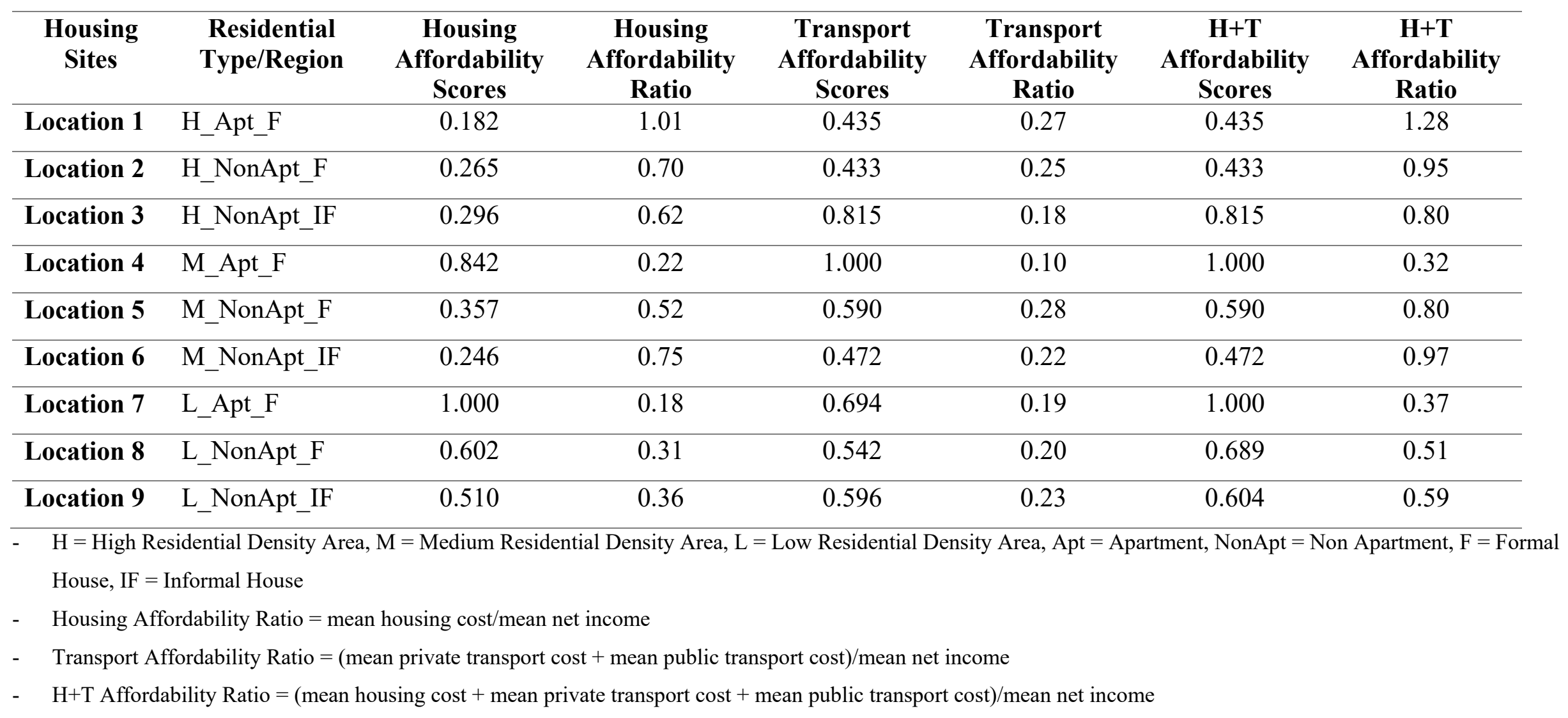


Table 5. Ranking of Affordability Performance

\begin{tabular}{|c|c|c|c|c|c|c|}
\hline $\begin{array}{l}\text { Ranking of } \\
\text { Affordability } \\
\text { Performance }\end{array}$ & $\begin{array}{l}\text { DEA Model 1: } \\
\text { Housing } \\
\text { Affordability }\end{array}$ & $\begin{array}{l}\text { Simple Ratio } \\
\text { Housing } \\
\text { Affordability }\end{array}$ & $\begin{array}{c}\text { DEA Model 2: } \\
\text { Transport } \\
\text { Affordability }\end{array}$ & $\begin{array}{c}\text { Simple Ratio } \\
\text { Transport } \\
\text { Affordability }\end{array}$ & $\begin{array}{c}\text { DEA Model 3: } \\
\text { H+T } \\
\text { Affordability }\end{array}$ & $\begin{array}{c}\text { Simple Ratio } \\
\text { H+T } \\
\text { Affordability }\end{array}$ \\
\hline 1 & Location 7 & Location 7 & Location 4 & Location 4 & Location 4,7 & Location 4 \\
\hline 2 & Location 4 & Location 4 & Location 3 & Location 3 & Location 3 & Location 7 \\
\hline 3 & Location 8 & Location 8 & Location 7 & Location 7 & Location 8 & Location 8 \\
\hline 4 & Location 9 & Location 9 & Location 9 & Location 8 & Location 9 & Location 9 \\
\hline 5 & Location 5 & Location 5 & Location 5 & Location 6 & Location 5 & Location 3,5 \\
\hline 6 & Location 3 & Location 3 & Location 8 & Location 9 & Location 6 & Location 2 \\
\hline 7 & Location 2 & Location 2 & Location 6 & Location 2 & Location 1 & Location 6 \\
\hline 8 & Location 6 & Location 6 & Location 1 & Location 1 & Location 2 & Location 1 \\
\hline 9 & Location 1 & Location 1 & Location 2 & Location 5 & & \\
\hline
\end{tabular}


However, there is an exception for location 4, associated with its nature as public rental housing where residents pay below market rents (up to 80\% lower). Thus, location 4 is highly affordable despite its strategic and accessible location. The results also suggest that housing costs in the inner city area (locations 1,2 , and 3 ) were deemed to be considerably unaffordable across all type of settlements, including the inner city informal housing (location 3 ) which only has 0.296 out of 1 for its affordability score. Households living in this inner city kampung might have substantially reduced their expenditure on rental equivalent cost, but they still have to pay more on housing related needs, mostly water. The survey data shows that households' expenditure on water in this location is second only to location 1, and is highest among other informal settlements.

For the transport affordability, the DEA affordability scores present an interesting spatial pattern, where there is no direct relationship between the distance of housing location from the city centre and the transport affordability. Urban theory would suggest that people living close to or in the inner city area would have better access to jobs, schools, public transit, and other urban services and facilities, would have lower demand for travel, especially by automobile, and thus less transport cost (Lipman, 2006; Litman, 2013; Mattingly and Morrissey, 2014). However, this is not necessarily the case in the BMA. Locations 1 and 2 failed to support the assumption to be the most affordable areas even if they have the highest transport accessibility. In the BMA case, income factors may contribute to the vehicle ownership and travel behavior, which then influences transport expenditure. Households with higher income levels (locations 1,2 and 5), tend to have more private vehicles, especially cars (see Figure 3) and use less public transport (see Figure 4.). They thereby spend relatively more on transport. On the other hand, lower income people in the city centre (location 3 ) gained the advantage of more access to public and active transport modes to reduce their transport expenses. This also applied to locations 4 and 7. Despite the distance from the city centre, households living in both these locations have the benefit of proximity to their unique daily travel purpose, which is not in the city core, and to reduce their transport cost. Location 4, the only location that is efficient in terms of transport affordability is a government built rental housing scheme especially targeted for student accommodation, with the university and its supporting facilities nearby. While location 7 is located nearby the industrial zone, so there are neighbourhood employment opportunities where most residents in the area work. Furthermore, both locations 4 and 7 are neighbourhoods where the surveyed households have zero car- 
ownership and even higher proportions of households with no private vehicle (see Figure 3), which may explain their lower transport costs. Due to the distinctive travel pattern of households in these locations, they may not have the urge to own and use private vehicles compare to other locations, and they are able to reduce their transport costs by using public transport or walking. However, this might not be the case with households living in location 3, 6 and 9, which have a relatively lower level of income of all locations. Their low expenditure on transport might also relate to 'suppressed travel demand', where they are forced to reduce their travel needs due to limited income or access to affordable transport modes (Mattioli et al., 2017).

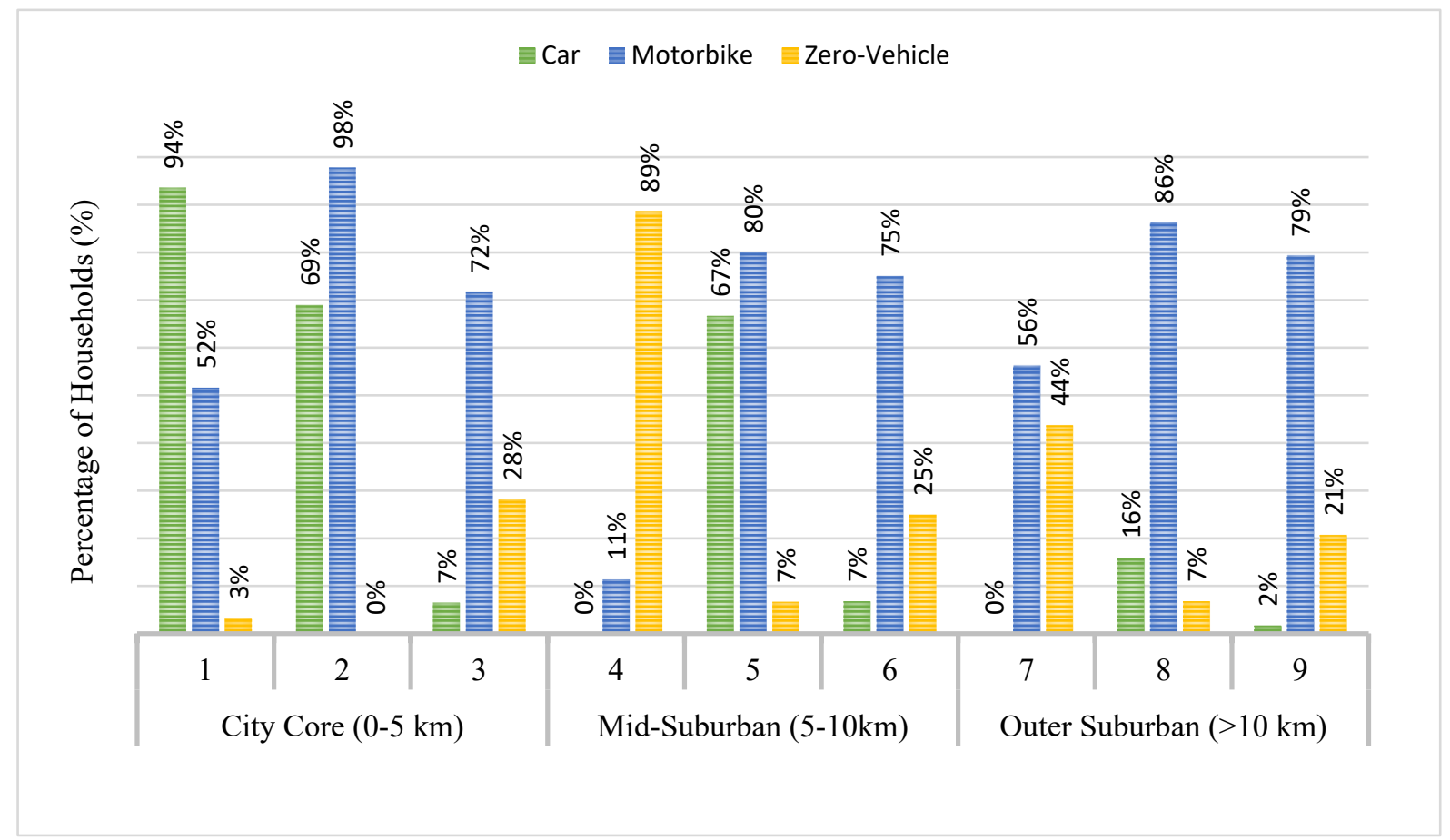

Figure 3. Vehicle Ownership Rate for each Housing Location

When transport and housing cost is combined (model 3), the results show that the transport cost affects the affordability performance of all residential areas observed in the BMA. However, any assumption that affordability is worse in suburban locations rather than in the inner city might be inappropriate. The $\mathrm{H}+\mathrm{T}$ affordability varied in each neighbourhood unit based on location and type of house. Locations 4 and 7 are the most affordable residential areas due to the combination of being a public rental area where the rent is controlled below the market price with closer proximity to jobs and schools. The next affordable locations are 3 and 8 . In these locations, households are making trade-offs between housing and transport cost to manage their budgets. Households in location 3 have more financial burden from housing costs but save from lower transport cost, while those living in location 8 save on housing price 
but spend higher on transport cost. These cross-subsidies make these locations relatively affordable when housing and transport cost both considered. However, housing and transport cost combined has no impact in shifting the affordability of locations 1 and 2. These locations remain expensive areas in the inner city with relatively higher income residents and preferences to use private vehicles.

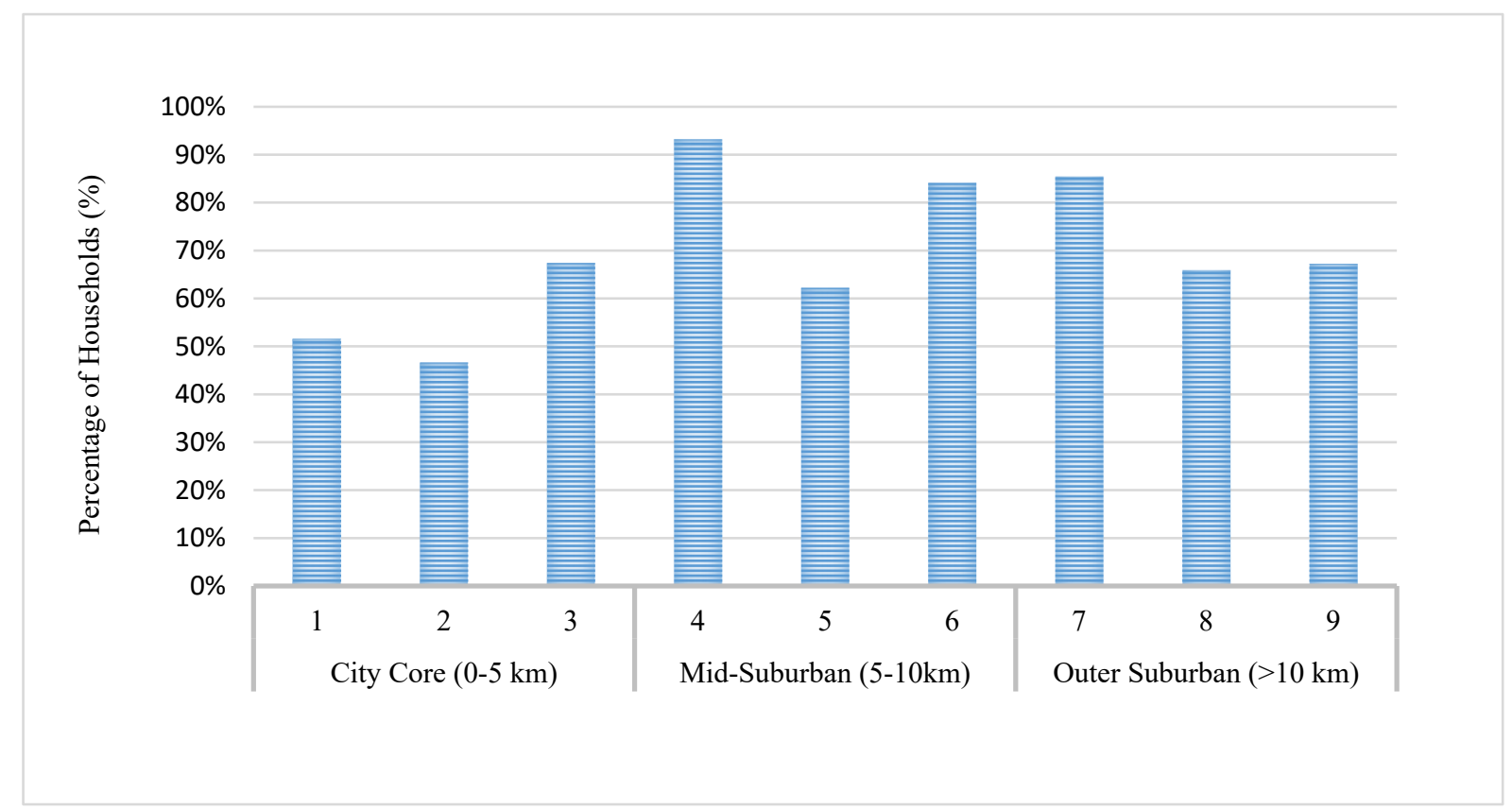

Figure 4. Percentage of Public Transport User for each Housing Location

Comparing the ranking results of the two methods (see Table 5), for the housing affordability model, both methods deliver similar results. However, it is interesting to note that in the case of transport affordability, there are some inconsistent results. For example, the cost/income ratio method suggests that transport is less affordable for households in location 5 (mid-suburb formal private housing) than in location 6, while the DEA affordability scores suggest the opposite. This case reveals that factors such as income and travel behavior may have confounding influences. The average household income in location 5 is the second highest of all locations and its private transport cost is the highest (see Table 2.), whereas location 6 has second lowest income on average and the fourth lowest private transport costs. The affordability ratio shows that a location with higher income level, where households are likely to spend relatively higher proportions of their income on transport, is assumed to have a lower affordability ratio, whereas the DEA score suggests that having higher transport expenses does not necessarily result in lower affordability. The simple ratio method assumes a monotonic relationship between proportion of transport expenses on income and affordability, which is 
not always the case in the real world. On the other hand, the DEA ranking method has incorporated the difference of locations being observed represented by the values of both output and input variables and demonstrates that higher proportion of transport expenses cannot simply relate to having lower affordability. Furthermore, from the combined housing and transport affordability model, it can be seen that the cost/income ratio method could not capture the effect of transport costs on the combined affordability, particularly the cross-subsidies between housing and transport costs effect in location 3, as the DEA method does. This result may be explained by the fact that the value of the transport costs variable in the cost/income ratio method is the lump sum of all transport costs, while the DEA method allows the private transport costs and public transport costs to be treated as a single variable, which made it possible to capture their effect on the overall calculation.

\subsection{Factors Influencing $H+T$ Affordability}

A Tobit model allows us to incorporate only one bound of the dependent variable while the DEA affordability score is constrained to fall between zero and one. Therefore, by taking the logarithm of the DEA efficiency scores, one could convert the dependent variable so that it has only one bound (Oum and $\mathrm{Yu}, 1994)$. For ease of interpretation, however, the signs of the regression coefficients are reported in accordance with the original form. By regressing the logarithm of affordability scores on the five explanatory variables, the estimation result is shown below.

Table 6 Results of Tobit regression model

\begin{tabular}{lccc}
\hline \multicolumn{1}{c}{ Regressor } & Coefficient & Std. Error & t value \\
\hline Motorcycle (MO) & $0.0110^{* * *}$ & 0.000821 & 13.4211 \\
\hline Distance (DI) & $-0.0447^{* * *}$ & 0.006727 & -6.6521 \\
\hline High-rise (HR) & $1.0748^{* * *}$ & 0.108578 & 9.8987 \\
\hline Informal house (IF) & $0.2252^{* * *}$ & 0.057789 & 3.8977 \\
\hline Main road (MR) & $-0.6318^{* * *}$ & 0.087279 & -7.2385 \\
\hline Number of obs. (N) $=9$ & $\overline{\boldsymbol{R}}^{\mathbf{2}}=\mathbf{0 . 8 5 9 5}$ \\
\hline
\end{tabular}

${ }^{* * *}$ indicate the significance of the estimates at the $1 \%$ levels.

A constant is excluded from the calculation due to its insignificance. All estimated parameters are statistically significant at the $p=0.01$ level, suggesting that these variables have contributions to the combined housing and transport affordability. The value of adjusted Rsquare shows that the explanatory variables included in the model can jointly explain the variation in the combined $\mathrm{H}+\mathrm{T}$ affordability. However, with a small number of observations, a 
great caution must be applied in interpretation, as the estimation coefficients might not be adequately predicted, nor it have enough statistical power. The results may have given an illustration about contributions of each explanatory factor to the combined $\mathrm{H}+\mathrm{T}$ affordability scores for this sample size, but it might not be statistically sufficient to predict the entire population.

$M O$, represents motorcycle ownership rate in each residential area that relates to the inexpensive, ease and speed of mobility. The results show that motorcycle ownership can raise the overall affordability but its effect is relatively small in comparison with all other factors. On average, a one unit increase in motorcycle ownership $(M O)$ will lead to an increase of the affordability score by $1.1 \%$. This may relate to the motorcycle's ubiquitousness in Bandung. Motorcycle purchases are relatively logical in cities with scarce road space, high traffic congestion, limited car parking availability, poor conventional public transport, and extreme heat. Motorcycle ownership may be an individual household's short-term solution to enhance their mobility, influencing their choice of housing location and travel behaviour.

$D I$ is a proxy variable for commuting distance. The regression model indicates that generally in the BMA, with its dominantly monocentric urban form (Kustiwan, 2010), a one $\mathrm{km}$ increase in distance from the CBD (the greatest employment centre) will decrease the combined affordability score by $4.47 \%$. The DEA affordability scores, discussed above, however, suggest that the Bandung Metropolitan Area may also demonstrate some form of polycentricity, where there are suburban centres functioning as a cluster of employment opportunities outside the inner city area that benefit the household living nearby in terms of economic activity, housing, and transport affordability.

$H R$ can be viewed as a proxy variable for higher density development in terms of optimised use of land for housing. The positive values of the result suggested that having a high-density housing type may possibly raise the combined housing and transport affordability. As urban developable land becomes scarce and expensive, encouraging vertical housing development might be an effective strategy to improve housing affordability, especially in major cities such as the BMA. Since 2007, the Indonesian government has pursued the National "Thousands of Towers" Program with a focus on the development of multi-family housing (apartments) for low-income households, both renters (RUSUNAWA) and homebuyers (RUSUNAMI). Even though many challenges such as land provision, limited government 
budget, and asset management still need to be resolved, this is a key policy that might assist with combined housing and transport affordability.

IF is a proxy variable for relatively low-cost housing provision. The values of the estimated parameter show that informal housing factor positively influences the overall affordability. In many developing countries, including Indonesia, this form of self-help housing remains an urban poor survival strategy (Tunas and Darmoyono, 2014), although the results of this study show that it may be becoming less affordable. Policy initiatives, especially for the slum and squatter areas, such as quality improvement programs for self-help housing, land titling, and micro-finance support for low-income housing, may assist, or may play a contrary role in increasing housing prices.

Finally, $M R$ is a proxy variable for accessible location, which is expected to result in lower transport cost due to more options to access less expensive travel modes (i.e. public transport). Nevertheless, the negative values of the estimated parameter suggest that residential areas with direct access to the main arterial roads are less affordable. The economic value of such locations drives the land cost up and decreases the level of housing affordability, while the expected reduction of transport cost is insufficient to outweigh housing cost and increase the combined $\mathrm{H}+\mathrm{T}$ affordability. Unreliable public transport and private vehicle dependency factors might be an influence. Thus, a more integrated transport and land-use policy such as modest road development, high capacity public transport investment and transit-oriented development (TOD) may be needed to ensure the advantages of better accessibility are provided across the BMA.

\section{Conclusions}

This paper supports the argument that incorporating transport cost into affordability measures can reveal the true housing affordability. Findings demonstrate that the affordability pattern of locations observed in the BMA changes when transport cost considered. Following the same concepts as the widely used $\mathrm{H}+\mathrm{T}$ measure, this paper presented an additional measure to evaluate the combined $\mathrm{H}+\mathrm{T}$ affordability in neighbourhood scale, using DEA modelling. In this study, both the DEA and costs/income ratio method share a number of similar results in location affordability ranking. However, using the DEA method offers further insights in relation to measuring and benchmarking of the housing and transport affordability. The strength of the DEA lies in the freedom of not being required to assign any pre-assumption for 
the functional form. All variables being analysed need not be subjectively weighted, which might incur errors. Instead, the model enables the variables to find the best way to provide the maximum efficiency or in this case, maximum affordability for each location being evaluated, to set up the benchmark. While previous measures might raise confusion by setting up an applicable threshold for the proportion of income spent on housing and transport suitable in global and local context, the DEA method may assist by providing the range of values from 0 to 1 for the affordability level that would have similar meaning in every observation, where the score of 1 is considered as the most affordable and set as the benchmark for the others with scores less than 1. The Tobit regression used in the proposed model also provides further information that leads to implications for housing, transport and urban planning and policy.

The DEA results showed that the affordable locations in conventional housing affordability measure are those located in the urban periphery. When transport cost is included, the impact on overall affordability differs based on the type of housing and income-related travel behaviour. The inner city slum area benefited from higher transport accessibility thus far less transport cost, which suggests household decisions to live close to the city core are reasonable. This study also indicated that to be able to capture the transport advantage of an accessible location, a pre-condition such as reliable and integrated public transport and landuse planning and design is necessary for Indonesian cities. Furthermore, policy and programs for affordable housing provision assisting self-built/informal housing, particularly to the very poor, and enhancing formal low-income housing practices, such as public rental housing, may offer some support to increase the affordability level. As shown in this study, low-cost rental apartment programs in Indonesia (RUSUNAWA) have become an affordable formal-housing option for low-income households that could not afford to buy a house or in need of temporary accommodation. The outcomes also suggest that higher-density housing development might assist affordability, thus current vertical housing development programs should be supported, especially in areas with soaring land prices such as the inner city area.

However, this study has limitations. An aggregated mean values were used as input and output variables for the calculations, which arguably is insufficient to account for data variability and may hide the variation between households. The small number of locations observed limits the generalisation of the results. Thus, further research with bigger sample sizes, in other locations, should be considered. Methodologically, future research may also explore multi-level or interval DEA models to explore affordability, to identify the advantages 
or different modelling formulations. To advance further understanding, further analysis on transport costs incorporating the household characteristics such as household's size, structure, and travel behaviour is needed to minimise the potential bias of defining and examining the transport cost and affordability, which is not addressed in this study. A future study integrating the value of time in estimating transport cost should also be undertaken since congestion is a major problem in many Indonesian cities. Lastly, the role of attitude in selecting residential location may also offer further understandings on the household decision in making a trade-off between housing and transport costs.

\section{Funding}

First author's $\mathrm{PhD}$ research was supported by funding from the Australian Department of Foreign and Trade. This research did not receive any specific grant from funding agencies in the public, commercial, or not-for-profit sectors.

\section{Acknowledgement}

The authors would like to thank the reviewer's valuable and helpful suggestions for improving this paper. 


\section{References}

Abbott, M., Doucouliagos, C., 2003. The efficiency of Australian universities: a data envelopment analysis. Economics of Education Review 22, 89-97.

Acolin, A., Green, R.K., 2017. Measuring housing affordability in São Paulo metropolitan region: Incorporating location. Cities 62, 41-49.

Adler, N., Golany, B., 2001. Evaluation of deregulated airline networks using data envelopment analysis combined with principal component analysis with an application to Western Europe. European Journal of Operational Research 132, 260-273.

Alirezaee, M.R., Howland, M., Van de Panne, C., 1998. Sampling size and efficiency bias in data envelopment analysis. Advances in Decision Sciences 2, 51-64.

Arnott, R., 2008. Housing policy in developing countries: The importance of the informal economy, The Commission on Growth and Development Working Paper. The World Bank, Washington DC, USA, pp. 1-32.

Asian Development Bank, 2010. Key Indicators for Asia and the Pacific 2010, 41 ed. Asian Development Bank, Phillipines.

Aurand, A., 2010. Density, housing types and mixed land use: Smart tools for affordable housing? Urban Studies 47, 1015-1036.

Austin, P.C., Steyerberg, E.W., 2015. The number of subjects per variable required in linear regression analyses. Journal of clinical epidemiology 68, 627-636.

Avkiran, N.K., 2006. Wight Restrictions - Real Estate Agents, in: Avkiran, N.K. (Ed.), Productivity Analysis in the Service Sector with Data Envelopment Analysis, Third ed. The University of Queensland, Austalia.

Avkiran, N.K., 2011. Association of DEA super-efficiency estimates with financial ratios: Investigating the case for Chinese banks. Omega 39, 323-334.

Badan Pusat Statistik, 2010. Census of Population. Badan Pusat Statistik, Jakarta. Badan Pusat Statistik, 2017a. Number of Motor Vehicles by Types, Indonesia 19492015.

Badan Pusat Statistik, 2017b. Persentase Rumah Tangga menurut Provinsi, Tipe Daerah dan Status Kepemilikan Rumah. Badan Pusat Statistik, Indonesia.

Banker, R.D., Charnes, A., Cooper, W.W., Swarts, W., Thomas, D., 1989. An introduction to data envelopment analysis with some of its models and their uses. Research in Governmental and Nonprofit Accounting 5, 125-163.

Barter, P., 2000. Urban transport in Asia: Problems and prospects for high-density cities. Asia-Pacific Development Monitor 2, 33-66.

Bowlin, W.F., 1998. Measuring performance: An introduction to data envelopment analysis (DEA), The Journal of Cost Analysis, pp. 3-27.

Bramley, G., 2012. Affordability, poverty and housing need: triangulating measures and standards. Journal of Housing and the Built Environment 27, 133-151.

Cao, M., Hickman, R., 2017. Car dependence and housing affordability: An emerging social deprivation issue in London? Urban Studies, 0042098017712682.

Carlson, D., Mathur, S., 2004. Does growth management aid or thwart the provision of affordable housing, in: Downs, A. (Ed.), Growth management and affordable housing: Do they conflict? Brookings Institution Press, Washington D.C., US, pp. 20-81.

Charnes, A., Cooper, W.W., Golany, B., Seiford, L., Stutz, J., 1985. Foundations of data envelopment analysis for Pareto-Koopmans efficient empirical production functions. Journal of Econometrics 30, 91-107.

Charnes, A., Cooper, W.W., Rhodes, E., 1978. Measuring the efficiency of decision making units. European journal of operational research 2, 429-444. 
Chiou, Y.-C., Chen, Y.-H., 2006. Route-based performance evaluation of Taiwanese domestic airlines using data envelopment analysis. Transportation Research Part E: Logistics and Transportation Review 42, 116-127.

Chiou, Y.-C., Lan, L.W., Yen, B.T., 2012. Route-based data envelopment analysis models. Transportation Research Part E: Logistics and Transportation Review 48, 415-425. CNT, 2010. Penny wise pound fuelish: New Measures of Housing + Transportation Affordability. Center for Neighborhood Technology.

Cooper, W.W., Seiford, L.M., Tone, K., 2007. Data envelopment analysis: a comprehensive text with models, applications, references and DEA-solver software, 2nd ed. Springer, New York.

Coulombel, N., 2018. Why housing and transport costs should always be considered together: A monocentric analysis of prudential measures in housing access. Transport Policy Volume 65, 89-105.

CTOD, CNT, 2006. The Affordability Index: A New Tool for Measuringthe True Affordability of a Housing Choice. The Brookings Institution, Washington DC. Dyson, R.G., Allen, R., Camanho, A.S., Podinovski, V.V., Sarrico, C.S., Shale, E.A., 2001. Pitfalls and protocols in DEA. European Journal of operational research 132, 245-259. Eurostat, 2014. Glossary: Housing cost overburden rate.

Friedman, L., Sinuany-Stern, Z., 1998. Combining ranking scales and selecting variables in the DEA context: The case of industrial branches. Computers and Operations Research 25, 781-791.

Gabriel, M., Jacobs, K., Arthurson, K., Burke, T., Yates, J., 2005. Conceptualising and Measuring The Housing Affordability Problem. Australian Housing and Urban Research Institute, Melbourne.

Golany, B.A., Roll, Y., 1989. An application procedure for data envelopment analysis. Omega 17, 237-250.

Gomez-Lobo, A., 2011. Affordability of public transport: A methodological clarification. Journal of transport Economics and Policy 45, 437-456.

Guerra, E., Kirschen, M., 2016. Housing Plus Transportation Affordability Indices: Uses, Opportunities, and Challenges, International Transport Forum, Paris.

Haas, P., Newmark, G., Morrison, T., 2016. Untangling Housing Cost and Transportion Interactions: The Location Affordability Index Model-Version 2 (LAIM2). Housing Policy Debate, 1-15.

Haas, P.M., Makarewicz, C., Benedict, A., Sanchez, T.W., Dawkins, C.J., 2006. Housing \& Transportation Cost Trade-Offs and Burdens of Working Households in 28 Metros. Center for Neighborhood Technology.

Halkos, G.E., Salamouris, D.S., 2004. Efficiency measurement of the Greek commercial banks with the use of financial ratios: a data envelopment analysis approach. Management accounting research 15, 201-224.

Harrell, F.E., 2001. Ordinal logistic regression, Regression modeling strategies. Springer, New York, pp. 331-343.

Helmig, B., Lapsley, I., 2001. On the efficiency of public, welfare and private hospitals in Germany over time: a sectoral data envelopment analysis study. Health Services Management Research 14, 263-274.

Herwangi, Y., Pradono, P., Syabri, I., Kustiwan, I., 2015. Making the Connection between Transport Disadvantage and Motorcycle Usage of Low-Income People in Yogyakarta Urbanized Area, Indonesia. Journal of the Eastern Asia Society for Transportation Studies 11, 90-109. 
Heston, A., Nakamura, A.O., 2009. Questions about the equivalence of market rents and user costs for owner occupied housing. Journal of Housing Economics 18, 273-279. Hill, R.J., Steurer, M., Waltl, S.R., 2017. Owner Occupied Housing in the CPI: Making the User Cost Approach Work and Why It Matters. University of Graz, Department of Economics.

Hoek-Smit, M., 2005. The housing finance sector in Indonesia. World Bank Isalou, A.A., Litman, T., Shahmoradi, B., 2014. Testing the housing and transportation affordability index in a developing world context: A sustainability comparison of central and suburban districts in Qom, Iran. Transport Policy 33, 33-39.

Jewkes, M.D., Delgadillo, L.M., 2010. Weaknesses of housing affordability indices used by practitioners. Journal of Financial Counseling and Planning 21, 43-52.

Joewono, T.B., Tarigan, A.K.M., Susilo, Y.O., 2016. Road-based public transportation in urban areas of Indonesia: What policies do users expect to improve the service quality? Transport Policy 49, 114-124.

Jones, P., 2017. Formalizing the Informal: Understanding the Position of Informal Settlements and Slums in Sustainable Urbanization Policies and Strategies in Bandung, Indonesia. Sustainability 9, 1436.

Juan, Y.-K., 2009. A hybrid approach using data envelopment analysis and case-based reasoning for housing refurbishment contractors selection and performance improvement. Expert Systems with Applications 36, 5702-5710.

Kao, C., Hwang, S.-N., 2008. Efficiency decomposition in two-stage data envelopment analysis: An application to non-life insurance companies in Taiwan. European journal of operational research 185, 418-429.

Karlaftis, M.G., 2004. A DEA approach for evaluating the efficiency and effectiveness of urban transit systems. European Journal of Operational Research 152, 354-364.

Kellet, J., Morrissey, J., Karuppannan, S., 2015. Drive till you Qualify: An Alternative View of Housing Affordability, State of Australian Cities Conference 2015, Gold Coast, Australia, pp. 1-9.

Kirigia, J.M., Emrouznejad, A., Sambo, L.G., 2002. Measurement of technical efficiency of public hospitals in Kenya: using data envelopment analysis. Journal of medical systems 26, 39-45.

Kustiwan, I., 2010. Sustainable Urban Form and Development (Study of Potencies of Urban Compaction at Bandung Metropolitan Area), Department of Environmental Studies Universitas Indonesia.

Kustiwan, I., Nuryanto, A.D., Kurniadi, I., 2007. Pengukuran Compactness sebagai Indikator Keberlanjutan Kota dan Kebutuhan Pengembangan Compact City pada Kawasan Tumbuh Pesat di Indonesia. Urban Planning and Design Research Group, Institut Teknologi Bandung, Bandung, Indonesia.

Kutty, N.K., 2005. A new measure of housing affordability: Estimates and analytical results. Housing policy debate 16, 113-142.

Leung, A., Burke, M., Yen, B., Cui, J., 2016. Oil vulnerability of Australian capital cities: A pilot study using Data Envelopment Analysis (DEA) for vulnerability benchmarking, Australasian Transport Research Forum (ATRF), 38th, 2016, Melbourne, Victoria, Australia.

Li, J., Xu, Y., 2016. Evaluating restrictive measures containing housing prices in China: A data envelopment analysis approach. Urban Studies 53, 2654-2669.

Lipman, B.J., 2006. A heavy load: The combined housing and transportation burdens of working families. Center for Housing Policy. 
Litman, T., 2013. Transportation Affordability: Evaluation and Improvement Strategies. Victoria Transport Policy Institute.

Litman, T., 2014. Affordable-Accessible Housing In A Dynamic City; Why and How To Increase Affordable Housing Development In Accessible Locations. Victoria Transport Policy Institute.

Martín, J.C., Román, C., 2006. A benchmarking analysis of Spanish commercial airports. A comparison between SMOP and DEA ranking methods. Networks and Spatial Economics 6, 111-134.

Mattingly, K., Morrissey, J., 2014. Housing and transport expenditure: socio-spatial indicators of affordability in Auckland. Cities 38, 69-83.

Mattioli, G., Lucas, K., Marsden, G., 2017. Transport poverty and fuel poverty in the UK: From analogy to comparison. Transport Policy 59, 93-105.

Merkert, R., Hensher, D.A., 2011. The impact of strategic management and fleet planning on airline efficiency-A random effects Tobit model based on DEA efficiency scores.

Transportation Research Part A: Policy and Practice 45, 686-695.

Monkkonen, P., 2013. Urban land-use regulations and housing markets in developing countries: Evidence from Indonesia on the importance of enforcement. Land Use Policy 34, 255-264.

Mujasi, P.N., Asbu, E.Z., Puig-Junoy, J., 2016. How efficient are referral hospitals in Uganda? A data envelopment analysis and tobit regression approach. BMC health services research 16, 230.

Mulliner, E., Smallbone, K., Maliene, V., 2013. An assessment of sustainable housing affordability using a multiple criteria decision making method. Omega 41, 270-279. Nasruddin, Ratnasari, A., 2014. Perbandungan Biaya Umum Transportasi Angkutan Umum dan Sepeda Motor Sebagai Moda Transportasi oleh Mahasiswa (Studi Kasus: Kampus Universitas Diponegoro Tembalang). Jurnal Teknik PWK 3, 406-417. Ndubueze, 0., 2007. Measuring housing affordability: A composite approach, ENHR 2007 International Conference 'Sustainable Urban Areas', Rotterdam, Netherland Nelson, A.C., Pendall, R., Dawkins, C.J., Knaap, G.J., 2004. The link between growth management and housing affordability: The academic evidence, in: Downs, A. (Ed.), Growth management and affordable housing: Do they conflict. The Brookings Institution, Washington DC, pp. 117-158.

Oum, T.H., Yu, C., 1994. Economic efficiency of railways and implications for public policy: A comparative study of the OECD countries' railways, Journal of transport Economics and Policy, pp. 121-138.

Peduzzi, P., Concato, J., Kemper, E., Holford, T.R., Feinstein, A.R., 1996. A simulation study of the number of events per variable in logistic regression analysis. Journal of clinical epidemiology 49, 1373-1379.

Poole, R., Ptacek, F., Verbrugge, R., 2005. Treatment of owner-occupied housing in the cpi. Federal Economic Statistics Advisory Committee (FESAC) on December 9, 2005. Saberi, M., Wu, H., Amoh-Gyimah, R., Smith, J., Arunachalam, D., 2017. Measuring housing and transportation affordability: A case study of Melbourne, Australia. Journal of Transport Geography 65, 134-146.

Sarkis, J., 2000. An analysis of the operational efficiency of major airports in the United States. Journal of Operations management 18, 335-351.

Schmidt, F.L., 1971. The relative efficiency of regression and simple unit predictor weights in applied differential psychology. Educational and Psychological Measurement 31, 699-714. 
Seiford, L.M., Thrall, R.M., 1990. Recent developments in DEA: the mathematical programming approach to frontier analysis. Journal of econometrics 46, 7-38.

Sepehrdoust, H., 2011. Efficiency measurement of housing sector; using DEA model, 2011 International Conference on Economics and Finance Research. IPEDR.

Sheth, C., Triantis, K., Teodorović, D., 2007. Performance evaluation of bus routes: A provider and passenger perspective. Transportation Research Part E: Logistics and Transportation Review 43, 453-478.

Sopha, B.M., Pamungkas, A.R., 2016. High fuel price: Will Indonesian shift to public transportation?, American Institute of Physics. The American Institute of Physics. Statistics of Jawa Barat, 2017. Jawa Barat in Figure 2017. Statistic Jawa Barat, Indonesia. Statistics of Sumedang, 2017. Sumedang in Figure 2017. Statistic Sumedang, Indonesia. Stone, M.E., 2006. What is housing affordability? The case for the residual income approach. Housing Policy Debate 17, 151-184.

Suparno, S.M., Marlina, E., 2007. Perencanaan dan Pengembangan Perumahan. Andi Publisher, Indonesia.

Susilo, Y.O., Joewono, T.B., 2017. Indonesia, in: Pojani, D., Stead, D. (Eds.), The Urban Transport Crisis in Emerging Economics. Springer International Publishing, Switzerland, pp. 107-126.

Susilo, Y.O., Santosa, W., Joewono, T.B., Parikesit, D., 2007. A reflection of motorization and public transport in Jakarta metropolitan area. IATSS research 31, 59-68.

Syabri, I., Pradono, Soegijanto, B.T., 2011. Embracing paratransit in Bandung Metropolitan Area, West Java, Indonesia.

Thanassoulis, E., Kortelainen, M., Johnes, G., Johnes, J., 2011. Costs and efficiency of higher education institutions in England: a DEA analysis. Journal of the Operational Research Society 62, 1282-1297.

Tunas, D., Darmoyono, L.T., 2014. Self-Help Housing in Indonesia, in: Bredenoord, J., Van Lindert, P., Smets, P. (Eds.), Affordable Housing in the Urban Global South:Seeking Sustainable Solutions. Routledge, New York, pp. 166-179.

Tunas, D., Peresthu, A., 2010. The self-help housing in Indonesia: The only option for the poor? Habitat International 34, 315-322.

Utomo, N.T., 2014. Affordable Housing Finance Policies on Indonesia. The World Bank. Venter, C., Behrens, R., 2005. Transport Expenditure: Is the 10\% Policy Benchmark Appropriate?, Proceedings of the 24th Southern African Transport Conference (SATC 2005), p. 13.

Vidyattama, Y., Tanton, R., Nepal, B., 2012. The Effect of Transport Costs on Housingrelated Financial Stress in Australia. Urban Studies 50, 1779-1795.

Widianto, S., 2014. Bandung termacet ketujuh se-Indonesia, Pikiran Rakyat. Pikiran Rakyat, Bandung.

Yates, J., Gabriel, M., 2006. Housing Affordability in Australia. Australia Housing and Urban Research Institute.

Zhao, X., Yue, W., 2010. A multi-subsystem fuzzy DEA model with its application in mutual funds management companies' competence evaluation. Procedia Computer Science 1, 2469-2478. 